\title{
Testing for drug and alcohol abuse at the workplace
}

\author{
Zoran Kavrakovski*, Katerina Jugreva, Biljana Bauer - Petrovska \\ Faculty of Pharmacy, University of "Ss Cyril and Methodius", Skopje, Republic of Macedonia
}

Received: November 2009; Accepted: December 2009

\begin{abstract}
Drug and alcohol abuse in the workplace represents a great risk to employee's health and safety. More than $50 \%$ of the employees worldwide are related to easily accessible drug abuse, while $70 \%$ of the employees are related to alcohol abuse in the workplace. Tests for detecting drug and alcohol abuse in the workplace should be part of a new regulation, compulsory for all employees in the Republic of Macedonia. Implementing this sort of testing program should at the same time be a step towards devising particular solutions that shall bring about greater safety in the working environment. A key element in the implementation is to devise and establish an adequate policy that shall determine the risk factors within a working establishment which shall clearly express its position regarding drug and alcohol abuse during working hours. Along with the risk factors, the policy may also include the program for testing both, employees and the ones who are about to be employed, for drug and alcohol abuse. In order to implement this sort of test, it must be in accordance with the Occupational Safety and Health Act (Official gazette of the Republic of Macedonia, $N^{o}$ 92/07, 2007) and a legal framework has to be defined, that shall regulate and solve numerous aspects of this issue, in order to fully implement the program for drug free working environment pursuant to the Declaration and the decrees of the United Nations General Assembly in 1998.
\end{abstract}

Key words: drugs and alcohol abuse, workplace, employees, drugs and alcohol testing.

\section{Introduction}

Drugs and alcohol are a plausible and definite risk for the employees' safety in the work environment (Ghodse, 2005). The abuse of alcohol and drugs can occur in any workplace. According to the statistics more than $50 \%$ of employees worldwide are connected with misuse of readily available drugs and $70 \%$ of them with alcohol abuse in the workplace (Bennett, Lehman, 2000). The abuse of alcohol and other drugs may damage both, the physical and the mental health (Commission for Occupational Safety and Health Act, MIAC, 2008). The impairment of behavior can result in increased risk of injury or harm (Drug \& Alcohol Information Centre, 2007) and this kind of abuse can also affect employees' productivity, safety and security, decision making, morale, as well as the organizational image and the community relations (Breugem et al., 2006).

zoka@ff.ukim.edu.mk
In the Republic of Macedonia testing for drug and alcohol abuse in the workplace should be a new legal regulation, mandatory for all employees. The introduction of the drug testing program should at the same time be an introduction to the process of solution making that will signify greater safety in the workplace. The Poison Control Center (PCC) (together with the toxicological laboratory) should be the carrier of the activities related to drug testing at the workplace as well as in developing new programs for testing, control and education that can help employers cope with this kind of issues.

\section{Considerations before conducting a drug testing program}

The first step in the risk management process is identifying hazards and hazards factors. When assessing whether alcohol and other drug use poses a safety and health hazard at the workplace, a range of factors should be considered. At some workplaces, the hazards associated with al- 
cohol and other drugs may be greater due to the nature of the workplace. Hazards or hazard factors that are important to consider in relation to increased risk of injury or harm if workers are impaired by alcohol or other drugs include operation of machinery, driving in the course of work, situations where concentrations or motor coordination is relied on to carry out a job, use of hazardous substances and performing duties as part of a team. Even when people return a zero alcohol or drug level they may still be impaired by the "hangover" effects that can last beyond the direct presence of the drug and create risks. The hazards and risks associated with alcohol and drug use at the workplace should be assessed in the same way as other occupational safety and health issues (Work Cover Corporation of South Australia, 2006).

According to the Occupational Safety and Health Act, (Official gazette of the Republic of Macedonia, $N^{\circ}$ 92/07, 2007), and according to other supporting regulations there is no specific reference to alcohol and other drugs. The solution is all parties at the workplace to comply with their general "duty of care" in relation to usage of alcohol and other drugs and their potential acute and chronic effects regarding safety and health in the workplace. Also there are other legislations that a relevant to alcohol and drugs but to keep in mind that these legislations are closely connected to a specific social and working area (Work Cover Corporation of South Australia, 2006). In order to conduct a drug testing and to achieve a drug-free workplace, employers must develop drug-free workplace program. A comprehensive drug-free workplace program generally includes developing a drug-free workplace policy. The primary aim of the policy is to provide a clear documented guide regarding the workplace's stance on drug and alcohol issues in relation to the workplace and to define the role of the employees, supervisors and in dealing with alcohol and drugs related work issues (Hunter Centre for Health Advancement, 2000). The program also includes supervisor training, employee education, employee assistance and drug testing. Employers may choose not to include all five components but it is recommended to explore all of them while developing a drug-free workplace program. Research shows that more components may lead to a more effective program. However, because every business is unique, there is not only one way to establish a drug-free workplace program. In order to conduct a drug testing it is necessary to coordinate this component with the Occupational Safety and Health Act in which no specific provisions are related to alcohol and drug testing. As a result employers are enabled to choose whether to test if risk assessments show particular risk, unless their organization is subjected to certain federal laws (ex. transportation drug-testing regulations, or aviation drug-testing regulations and others), as well as to keep in mind that industries may have industry-specific legislations or codes that deal with alcohol and other drugs at the workplace and these should be referred to, and also the drug testing is a contentious area (Work Cover Corpo- ration of South Australia, 2006). It is recommendable for the employer before conducting any drug-testing program to have a written policy that clearly outlines the necessity for the drug-testing. Therefore employers should carry out risk assessment in order to establish the nature of the policies and programs according to the level of risk at the workplace.

\section{Testing for drugs and alcohol abuse at the workplace}

Drug and alcohol abuse in the workplace is an issue that poses great threat to employees health, safety and security. That is why analysis is essential. According to the Occupational Safety and Health Act (Official gazette of the Republic of Macedonia, $\left.N^{\circ} 2 / 07,2007\right)$, employers are obliged to undertake necessary measures regarding the health and safety of the employees. By doing this, the potential and specific dangers may be identified, resulting in taking proper actions for their on time elimination, isolation, as well as minimization of their influence.

The Poison Control Centre (PCC) may take part in developing certain measures and activities in order to help employers interested in the development and improvement of the programs for testing drug and alcohol abuse in the workplace, by organizing educational courses, workshops and providing advice regarding the benefits and the significance of the health and safety effects of these analysis in both, the working and the living environment.

For great deal of employers, the drug testing program as well as the alcohol testing program may bring about less absence from work, decline in team changes when working in shifts, improvement of the health, safety and morale of the employees, as well as increase in work efficiency and productivity.

\section{What is to be tested}

After conducting the drug-testing program different procedures can be carried out in order to test alcohols, cocaine, cannabinoids, designer drugs, prescribed medications not used for medical purposes (such as opiate analgesics, sedative hypnotics), inhalants, hallucinogens, narcotics and also active substances within the drug which have significant effect on CNS. The material that is to be tested includes different kinds of samples, preferably urine, saliva and hair which are less painful to collect as well as blood samples which represent a bit more painful procedure.

\section{Group of people to be tested and when to be tested}

The drug and alcohol testing in the workplace can be carried out not only on all new applicants before being employed in the service, but on the already employed ones as well. This is of great significance for employees in a workplace with high risk of injury or illness, as well as other 
job positions defined as high-risk and sensitive in terms of health and safety of the employees, their associates and customers. These job positions include the organic-chemical and oil industry, construction, aviation, tourism, transportation of passengers, technical and health care, police and military structures, working with dangerous and harmful chemicals, explosives, etc. The drug and alcohol abuse testing program shall be implemented in the following cases:

Pre-employment testing: drug and alcohol abuse affects the person's behavior, psychophysical ability, and work efficiency;

Post accident/incident testing: employees that have been directly involved in certain incidents must immediately undertake testing in order to discover whether the drug and/or alcohol abuse, as well as medicament abuse (with significant effect on the CNS) are the factors that affected the accident;

Intentional testing: employees are being tested due to suspicion of drug and/or alcohol abuse;

Periodic testing or random testing: all employees or a certain group of employees working at a high risk and safety-sensitive job position are being tested randomly, without being given previous notice. The testing may include:

- random selection of employees from a certain team; or

- $\quad$ testing each employee within a team, randomly selected, several times in a defined period of time.

Also, the testing may be performed on people (such as: suspended workers) who are involved in rehabilitation programs, once again by means of random choice in 12 to 24 months, in order to obtain better monitoring of the therapy efficiency. The decision for performing periodic testing on employees must be in accordance with the protection of privacy and human rights.

\section{Current position of the testing for drugs and alcohol abuse at the workplace in other countries}

According to other countries' stance (USA, Canada, Australia), the introduction of the alcohol and drug testing should be made in consultation with employees, an Occupational Health and Safety (OHS) representatives and union representatives. The drug testing can be introduced if a risk assessment has identified that there are risks involved in undertaking certain activities whilst under the influence of alcohol and other drugs. Privacy, confidentiality and the legal position of employees and management should also be considered. The alcohol and other drug testing should be implemented as part of a comprehensive alcohol and drug program with appropriate safeguards, clear policy and procedures, and provision of education and counseling. The alcohol and drug testing in the workplace should also be introduced if there are existing legislative provisions, such as those relating to rail safety workers, passenger transport workers and heavy vehicle drivers. There is also legislation prohibiting employees from working while intoxicated in the mining and aviation industries (Commission for Occupational Safety and Health Act, MIAC, 2008).

\section{Current position of the testing for drugs and alcohol abuse at the workplace in the Republic of Macedonia}

Currently, in the Republic of Macedonia the programs for drug and alcohol testing among employees are still a legal challenge. In order to implement a drug-free workplace program and be able to conduct testing for drugs and alcohol abuse at the workplace, it is necessary to establish a legal frame that covers many aspects. This can be achieved by imposing regulation that enables:

- implementation of the new safety strategy in the work environment;

- monitoring danger of hazards;

- conducting prevention, education, rehabilitation;

- clear definition of the rights and accountability of employees and employers;

Also it is very important to set rulebooks for proper and methodological collection of samples for detecting drugs and alcohol presence in urine and blood as well as to set rulebook for establishing referential values of some drugs and their metabolites in blood, urine, saliva hair etc.

\section{Conclusion}

A constructive step for employers to address alcohol and other drugs safety and health issues is to develop a workplace alcohol and other drugs policy, with supporting procedures, which address specific circumstances at the workplace. The development of a written policy and supporting procedures provides an opportunity to develop a range of management strategies designed to deal with issues that could arise. One important strategy for preventing problems is to provide information, education and training to all people at the workplace about the effects of alcohol and other drugs and their risks to safety and health, and the alcohol and other drugs policy and supporting procedures if developed. Providing information about alcohol and other drugs also contributes to the development of a workplace culture where workers are aware of the potential risks to safety and health and are prepared to encourage each other to work safely.

\section{References}

Bennett, J., Lehman,W., 2000. Preventing workplace substance abuse. Beyond drug testing to wellness. American Psychological Association Washington, DC.

Breugem, L. et al., 2006. The Impact of Alcohol and Other Drugs in the Workplace. SafeWork SA, 1-101.

Commission for Occupational Safety and Health Act, MIAC., 2008. Alcohol and other drugs in the workplace. Guidance 
Note, WA, 1-27.

Drug \& Alcohol Information Centre., 2007. Why worry about alcohol and other drugs in the workplace? Drug ARM National Office, Australasia, Brisbane, 1-4.

Ghodse, H., 2005. Addiction at work: tackling drug use and misuse in the workplace. Gower Publishing Ltd, UK.

Hunter Centre for Health Advancement., 2000. A guide for implementing a drug and alcohol policy in the workplace. NSW, 1-5.
Official gazette of the Republic of Macedonia, $N^{o}$ 92/07., 2007. Occupational Safety and Health Act.

Work Cover Corporation of South Australia., 2006. Alcohol and other drugs in the workplace. Guide to developing a workplace alcohol and other drugs policy. Work Cover Authority of NSW, Sydney, 1-28.

\title{
Резиме
}

\section{Испитување на злоупотребата на дроги и алкохол на работното место}

\author{
Зоран Кавраковски*, Катерина Југрева, Билјана Бауер - Петровска \\ Фармацевтски Факултет, Универзитет “Св. Кирил и Методиј” Скопје, Р. Македонија
}

Клучни зборови: злоупотреба на дроги и алкохол, работно место, вработени, тестирање на дроги и алкохол.

Злоупотребата на дрогите и алкохолот на работното место претставува голем ризик по здравјето и безбедноста на вработените. Повеќе од 50\% од вработените во светски рамки се поврзуваат со злоупотреба на лесно достапни дроги, а 70\% од нив со злоупотреба на алкохол на работното место. Испитувањата за злоупотреба на дрогите и алкохолот во работната средина треба да биде нова законска обврска, задолжителна за сите вработени во Република Македонија.

Воведувањето на програмата за испитување на оваа проблематика треба истовремено да биде и вовед во креирањето на одредени решенија кои ќе значат поголема безбедност во работната средина. Клучен елемент претставува креирањето и воспоставувањето на соодветна полиса каде преку утврдување на ризик факторите во работната установа јасно ќе се дефинираат нејзините ставови во однос на злоупотребата на дрогите или алкохолот во текот на работното време. Согласно ризик факторите, во полисата може да биде вклучена и програмата за испитување на дроги и алкохол кај вработените, како и кај лица кои допрва треба да се вработат. За да се спроведе ваквото испитување мора да постои усогласување со Законот за безбедност и здравје при работа (Службен весник на РM, бр. 92/07, 2007) и истовремено да се изготви и дефинира правна рамка со која ќе се регулираат и решат многу аспекти од оваа проблематика, сѐ со цел да се имплементира програмата за работна средина без дроги согласно Декларацијата и заложбите на Генералното собрание на Организацијата на Обединетите Нации (ООН) од 1998 година. 